\title{
Nurmisäilörehun laadun merkitys lihanaudan ruokinnassa
}

\author{
Arto Huuskonen \\ Maa-ja elintarviketalouden tutkimuskeskus, Kotieläintuotannon tutkimus, Halolantie 31A, 71750 \\ Maaninka,arto.huuskonen@mtt.fi
}

\section{Tiivistelmä}

Tämän työn tavoitteena on selvittää nurmisäilörehun laadun merkitystä kasvavien lihanautojen ruokinnassa. Esitys perustuu MTT:1lä toteutettuihin lihanautojen ruokintakoeaineistoihin sekä soveltuvin osin myös kansainväliseen tutkimustietoon. Lihanautoja voidaan kasvattaa tavoiteltuun teuraspainoon monilla erilaisilla rehuyhdistelmillä. Eräs ruokinnan keskeisiä kysymyksiä on karkearehun ja väkirehun suhde. Lihanaudan ruokinnassa väkirehuprosentti voi teoriassa olla $0-80$ välillä. Karkearehun määrän on oltava vähintään noin $20 \%$ syödystä kuiva-aineesta, jotta eläimen pötsitoiminnot säilyisivät normaaleina. Kuitenkin jo 60-70 prosentin väkirehutasoilla on tutkimuksissa havaittu selviä negatiivisia vaikutuksia, jotka näkyvät esimerkiksi rehun sulatuksen heikkenemisenä. Tärkein yksittäinen säilörehun ruokinnallista laatua kuvaava mittari on D-arvo eli sulavan orgaanisen aineen osuus kuivaaineesta (\%). Lihanaudoille syötettävän säilörehun suositeltava D-arvo on ruokintatutkimusten perusteella $68-71 \%$. Varhain korjattua säilörehua syöneet naudat ovat kasvaneet ruokintatutkimuksissa paremmin kuin myöhemmin korjatulla säilörehulla ruokitut. Hyvälaatuista nurmisäilörehua käytettäessä väkirehun lisäyksellä saatavat kasvun lisäykset ovat yleensä varsin pieniä. Kun säilörehun sulavuus huononee, väkirehua kannattaa käyttää enemmän. Optimaalinen väkirehutaso sonnin ruokintaan on tilakohtainen ratkaisu, joka riippuu käytössä olevasta rehuntuotantokapasiteetista ja ostoväkirehun hinnasta. Eläimen syömä rehumäärä vaikuttaa yleensä varsin suoraviivaisesti energian saantiin ja kasvutuloksiin. Näin ollen tekijöillä, joilla voidaan vaikuttaa rehun syöntiin, voidaan vaikuttaa myös kasvutuloksiin. Esimerkiksi säilörehun laadulla on suuri vaikutus rehun syöntiin ja eläinten kasvuun. Säilörehun syöntiin vaikuttavat muun muassa rehun kuiva-ainepitoisuus, säilönnällinen laatu, kuitupitoisuus, orgaanisen aineen sulavuus ja kuidun sulavuus. Rehun kuiva-aine- ja sokeripitoisuuden lisääntyminen lisäävät yleensä kuiva-aineen syöntiä. Vastaavasti taas noussut voihappopitoisuus ja korkea ammoniumtyppipitoisuus vähentävät syöntiä. Säilörehun korkea ammoniumtyppi- ja voihappopitoisuus ovat merkkejä siitä, että rehu on virhekäynyttä ja/tai rehun käymisprosessi on ollut liiallista. Tällaisissa tapauksissa rehu on yleensä tehty ilman säilöntäainetta tai säilötty biologisilla säilöntäaineilla. Esimerkiksi hyvin märissä olosuhteissa biologisen säilönnän epäonnistumisriski on suuri. Märän rehun suurempi pilaantumisriski johtuu siitä, että biologisilla säilöntäaineilla säilöttävässä rehumassassa pitäisi olla sokeria noin 2,5\% rehumassan tuorepainosta. Näin ollen rehumassan kuiva-ainepitoisuus tulisi olla 30-35\%, jotta sokerimäärä olisi riittävä. Kotimaisten säilörehututkimusten perusteella rehun säilöntä vaikuttaa myös naudan pötsissä tapahtuvaan mikrobivalkuaisen tuotantoon. Kun tutkimuksissa on ruokittu nautoja joko rajoitetusti käyneellä, muurahaishapolla säilötyllä säilörehulla tai pitemmälle käyneellä, biologisesti säilötyllä rehulla tulokset ovat olleet selkeitä. Pötsin mikrobivalkuaisen tuotanto on tehostunut merkitsevästi happosäilöttyjä rehuja käytettäessä. Kasvavan lihanaudan ruokinnassa tämä tarkoittaa muun muassa sitä, että kun käytetään rajoitetusti käynyttä säilörehua, on rehuvalkuaisen tarve pienempi kuin pitkälle käynyttä säilörehua käytettäessä.

Asiasanat: naudanlihantuotanto, sonnit, ruokinta, nurmisäilörehu, sulavuus, säilönnällinen laatu 


\section{Johdanto}

Tämän työn tavoitteena on kartoittaa nurmisäilörehun laadun merkitystä kasvavien lihanautojen ruokinnassa. Työ perustuu MTT:1lä toteutettuihin lihanautojen ruokintakoeaineistoihin sekä soveltuvin osin myös muihin kotimaisiin ja kansainvälisiin tutkimuksiin.

\section{Nurmisäilörehun D-arvo}

Nurmikasvien vanhetessa niiden soluseinäpitoisuus suurenee ja soluseinien eli kuidun sulavuus huononee (Rinne 1995). Sen vuoksi varhaisella kehitysasteella korjattu nurmi sulaa paremmin nautojen ruoansulatuskanavassa ja sisältää siten enemmän eläimelle käyttökelpoista energiaa. Nautojen ruokinnassa sulavan orgaanisen aineen määrä rehun kuiva-aineessa eli D-arvo on Suomessa tärkein karkearehun ravitsemuksellista laatua kuvaava tekijä (Manninen ym. 2006). D-arvon vaikutusta maidontuotantoon on meillä tutkittu runsaasti (esim. Rinne 2000, Kuoppala ym. 2004). Sen sijaan D-arvon vaikutusta naudanlihantuotantoon on tutkittu huomattavasti vähemmän. Mannisen ym. (2006) tutkimuksessa korkean D-arvon (75 \%) nurmisäilörehulla ruokitut hereford-sonnit kasvoivat päivässä 186 g paremmin $(\mathrm{P}<0,01,1795$ vs. $1609 \mathrm{~g} / \mathrm{pv})$ kuin hyvän $\mathrm{D}$-arvon $(70 \%)$ säilörehulla ruokitut sonnit. Korkean D-arvon säilörehulla ruokituilla sonneilla nettokasvu ylitti kilogramman ollen keskimäärin $1028 \mathrm{~g} / \mathrm{pv}$, kun se hyvän D-arvon säilörehulla ruokituilla sonneilla oli keskimäärin $912 \mathrm{~g} / \mathrm{pv}(\mathrm{P}<0,05)$ (Manninen ym. 2006). Sonnien päiväkasvu lisääntyi siten Mannisen ym. (2006) tutkimuksessa keskimäärin $37 \mathrm{~g}$ ja nettokasvu $23 \mathrm{~g}$, kun säilörehun D-arvo nousi yhdellä prosentilla. Myös maitorotuisilla sonneilla tehdyissä kotimaisissa kokeissa eläimet ovat syöneet varhain korjattua säilörehua enemmän ja kasvaneet nopeammin kuin myöhemmin korjattua säilörehua saaneet sonnit (Aronen \& Toivonen 1995, Aronen ym. 1995, Joki-Tokola ym. 1995). Ulkomaisissa tutkimuksissa aikaisin korjattua säilörehua saaneet naudat ovat johdonmukaisesti kasvaneet nopeammin kuin myöhemmin korjatulla säilörehulla ruokitut naudat (esim. Steen \& McIlmoyle 1982, 1985, Flipot ym. 1984, Steen 1984, Nordang \& Hole 1987, Martinsson 1990, Steen 1992).

Lihanautoja voidaan kasvattaa tavoiteltuun teuraspainoon useilla erilaisilla rehuyhdistelmillä. Eräs ruokinnan keskeisiä kysymyksiä on karkearehun ja väkirehun suhde. Lihanaudan ruokinnassa väkirehuprosentti voi teoriassa olla 0 - 80 välillä. Karkearehun määrän on oltava vähintään noin $20 \%$ syödystä kuiva-aineesta, jotta eläimen pötsitoiminnot säilyisivät normaaleina. Kuitenkin jo 60-70 prosentin väkirehutasoilla on tutkimuksissa havaittu selviä negatiivisia vaikutuksia, jotka näkyvät esimerkiksi rehun sulatuksen heikkenemisenä (Huuskonen ym. 2007). Säilörehun sulavuuden paraneminen näkyy parempina kasvutuloksina lihanaudoilla ja väkirehulisäyksellä saadut tuotosvasteet pienenevät säilörehun sulavuuden parantuessa (Martinsson 1990, Steen ym. 2002). Hyvälaatuiseen säilörehuun perustuvalla ruokinnalla onkin todettu päästävän voimakkaiden väkirehuruokintojen kanssa varsin kilpailukykyisiin kasvutasoihin (Muir ym. 1998, Steen ym. 2002). Hyvälaatuista nurmisäilörehua käytettäessä väkirehun lisäyksellä saatavat kasvun lisäykset ovat yleensä varsin pieniä (Huuskonen 2009). Kun säilörehun sulavuus huononee, väkirehua kannattaa käyttää enemmän. Optimaalinen väkirehutaso sonnin ruokintaan on tilakohtainen ratkaisu, joka riippuu käytössä olevasta rehuntuotantokapasiteetista ja ostoväkirehun hinnasta. Rehujen hintasuhteiden muutokset muuttavat taloudellisesti optimaalista ruokintaa. Esimerkiksi rehuviljan edullisuus suhteessa karkearehuun houkuttelee lisäämään väkirehun käyttöä lihanautojen ruokinnassa.

Kaikille lihanautatiloille sopivaa nurmisäilörehun D-arvotavoitetta on mahdoton antaa, koska se riippuu mm. käytettävissä olevasta peltopinta-alasta. Esimerkiksi jos tilalla on käytössä runsaasti nurmialaa, tilan kannattaa panostaa säilörehun laadun parantamiseen ja sitä kautta tuotoksen lisäykseen ja väkirehun tarpeen vähentämiseen. Kuitenkaan yleensä ei kannata tavoitella paljon yli 70 prosentin olevia D-arvoja, koska tällöin satotaso jää pieneksi ja säilörehun valkuaispitoisuus yleensä nousee tarpeettoman suureksi. Jos tilalla on riittävästi nurmialaa eikä säilörehun laatua ole mielekästä parantaa, on oman rehuviljan tuotannon lisääminen usein järkevä vaihtoehto. Jos puolestaan nurmiala on rajoittava tekijä, ei säilörehun sulavuutta kannata maksimoida, vaan järkevintä lienee pyrkiä hieman matalampaan sulavuuteen ja suureen satoon sekä käyttää enemmän väkirehua ruokinnassa.

\section{Nurmisäilörehun raakavalkuaispitoisuus}

Kun nurmikasvuston käytettävissä on enemmän typpeä, nurmisadon kuiva-ainesato kasvaa, mutta kuiva-ainepitoisuus pienenee (Rinne ym. 1995). Myös kuiva-aineen kuitupitoisuus on tällöin usein 
pienentynyt. Raakavalkuaispitoisuus ja ei-valkuaistypen osuus raakavalkuaisesta sen sijaan suurenevat (Thorvaldsson \& Andersson 1986, Lindberg \& Lindgren 1988). Typpilannoituksen vaikutus nurmikasvien orgaanisen aineen sulavuuteen on vaihteleva ja vähäinen (Thorvaldsson \& Andersson 1986, Lindberg \& Lindgren 1988, Van Vuuren ym. 1992).

Säilörehun korkea raakavalkuaispitoisuus vaikuttaa negatiivisesti typen hyväksikäyttöön ja lisää kotieläintuotannon ympäristökuormitusta. Typen hyväksikäytön kannalta ihanteellisessa säilörehussa olisi raakavalkuaista 12-13 \% ja rehun sulavuus olisi hyvä (D-arvo yli 67) (Huuskonen ja Ojajärvi 2006). Käytännössä on usein kuitenkin hankala tuottaa säilörehua, jonka raakavalkuaispitoisuus on suhteellisen matala, jos tavoitellaan korkeaa satotasoa. Märehtijän typpihävikkejä voidaan teoriassa vähentää pienentämällä dieetin typpipitoisuutta, vähentämällä rehuvalkuaisen pötsihajoavuutta ja tehostamalla mikrobien kykyä sitoa pötsissä hajonneet typelliset yhdisteet mikrobivalkuaiseksi (Tamminga 1992). Kasvavilla lihanaudoilla dieetin typpipitoisuuden pienentäminen lienee useissa tapauksissa varteenotettava vaihtoehto, sillä Huuskonen (2009) raportoi, että valkuaislisän antaminen yli puolen vuoden ikäiselle maitorotuiselle sonnille on tarpeetonta, kun eläimet ruokitaan hyvälaatuisella säilörehulla (D-arvo yli $65 \%$, rehun säilönnällinen laatu hyvä) ja viljapohjaisella väkirehulla kohtuullisin väkirehutasoin (väkirehuprosentti 25-70\%). Sen sijaan rehuvalkuaisen pötsihajoavuuden vähentäminen ei vähennä typpitappioita, ellei typen pidättyminen kudoksiin (tai lypsylehmillä maitoon) lisäänny. Esimerkiksi Tuorin (1992) ja Varvikon ym. (1995) tutkimuksissa rypsirouheen höyrykuumennuskäsittely valkuaisen pötsihajoavuuden vähentämiseksi ei lisännyt typen erittymistä maitoon.

Säilörehuun perustuvassa nautojen ruokinnassa on mahdollista yrittää tehostaa pötsin mikrobisynteesiä. Mikrobisynteesi voi jäädä suhteellisen tehottomaksi, jos säilörehu on säilönnän aikana käynyt voimakkaasti ja sisältää siten runsaasti käymisen lopputuotteita, joista pötsimikrobit eivät juuri saa energiaa (Chamberlain 1987). Myös valkuaisaineiden hajoaminen säilönnän aikana saattaa olla mikrobeille haitallista. Mikrobien kasvu voi tehostua, kun käytettävissä on pelkän ammoniakin sijasta aminohappoja ja peptidejä (Prins 1977).

\section{Nurmisäilörehun kuitupitoisuus}

Aiemmin rehujen kuitupitoisuus ilmoitettiin raakakuituna. Nykyään raakakuitua käytetään enää väkirehujen energia- ja valkuaisarvon laskennassa. Raakakuitua korvaamaan on kehitetty detergenttikuituanalyysit (Van Soest ym. 1991). Neutraalidetergenttikuitu (NDF) kuvaa rehun solunseinämäaineksen kokonaismäärää. NDF-kuituanalyysi jakaa rehun hiilihydraatit solunseinä- ja solunsisällyshiilihydraatteihin. Tämä jako on märehtijän ruoansulatuksen kannalta parempi kuin aikaisemmin käytössä ollut jako raakakuituun ja typettömiin uuteaineisiin (Huhtanen 2003).

Kuidun laadulla on ratkaiseva merkitys tasapainoisessa ruokinnassa. Jos hyvällä kuidun laadulla tarkoitetaan, että kuidulla on pureskelua ja märehtimistä lisäävät rakenneominaisuudet (pötsin pH:n ylläpitäminen) sekä korkea potentiaalinen sulavuus ja suuri sulatusnopeus (runsas ravintoaineiden saanti), hyvälaatuinen säilörehu ja laidunruoho ovat ainoat rehut, jotka täyttävät nämä kolme ominaisuutta (Huhtanen 2003). Vaikka sulavasta kuidusta puhuttaessa usein tarkoitetaan kuitupitoisia väkirehuja, on hyvin sulavassa säilörehussa enemmän sulavaa kuitua kuin esimerkiksi melassileikkeessä. Säilörehu onkin ylivoimaisesti tärkein sulavan kuidun lähde Suomessa.

NDF-kuitua voidaan periaatteessa käyttää apuna ruokinnan suunnittelussa. Sen perusteella voidaan arvioida, onko rehuannoksen kuitupitoisuus liian pieni pötsin normaalien toimintojen ylläpitämisen kannalta (Huhtanen 2003). Toisaalta voidaan arvioida rajoittaako liian suuri kuitupitoisuus rehujen syöntiä. Riittävän suuri kuitupitoisuus rehuannoksessa on tarpeen pötsin normaalin $\mathrm{pH}: n$ ylläpitämiseksi. Tällä hetkellä ei ole kuitenkaan riittävästi kotimaista tutkimustietoa tarkan NDF-kuidun minimitason määrittämiseksi. Pohjois-Amerikassa on sen sijaan tehty paljon tutkimusta lihanautojen kuidun tarpeesta ja kuidun puutteeseen liittyvistä terveysongelmista feedlot-kasvattamoissa (esimerkiksi: Mader ym. 1991a,b, Galeyan \& Eng 1998, Nagaraja \& Chengappa 1998, Owens ym. 1998, Ramsey ym. 2002). Pohjois-Amerikassa saatuja tuloksia ei voida kuitenkaan soveltaa suoraan Suomeen monestakaan syystä. Pohjois-Amerikassa käytettävien lihanaudan rehuannosten koostumukset poikkeavat suuresti suomalaisista vastaavista, ja lisäksi Pohjois-Amerikassa kasvatuskausi yleensä jakaantuu hyvin ekstensiiviseen preeriavaiheeseen ja intensiiviseen feedlot-vaiheeseen. Tämä jälkimmäinen vaihe on sen verran lyhyt, ettei se ehdi todennäköisesti vaurioittaa maksaa samalla tavalla kuin 1,5 vuotta jatkuva intensiivinen ruokinta. Toinen asia on se, että Pohjois-Amerikassa sisäelimiä ei ilmeisesti juuri käytetä elintarvikkeena, joten asian taloudellinen merkityskin on pienempi. Voi myös olla, että Poh- 
jois-Amerikassa käytettävillä lisäaineilla (esim. monensin) on ehkäisevä vaikutus esimerkiksi maksavaurioihin.

Suomessa ei ole välttämättä edes mahdollista määrittää selkeää minimitasoa NDF-kuidulle, koska asiaan vaikuttavat kuitupitoisuuden lisäksi monet muut tekijät. Esimerkiksi kuitupitoisten väkirehujen (melassileike, ohrarehu) NDF-kuidun vaikutus on huonompi kuin säilörehun. Samaten huonosti sulavan karkearehun "kuituvaikutus" on suurempi kuin hyvin sulavan. Näin ollen rehuannoksen, joka koostuu huonosti sulavasta säilörehusta ja viljasta, NDF-kuidun minimitaso on pienempi kuin rehuannoksen, joka koostuu hyvin sulavasta säilörehusta ja runsaasti ns. sulavaa kuitua sisältävästä väkirehusta. Edellisellä dieetillä pötsi voi toimia normaalisti $30 \%$ :n NDF-kuitupitoisuudessa, mutta jälkimmäisellä minimi voi olla jopa $40 \%$ (Huhtanen 2003).

Ennen kuin koko rehuannoksen NDF-suosituksia kasvaville lihanaudoille voidaan antaa, ohjeistuksena voidaan todennäköisesti parhaiten käyttää karkearehun NDF-kuidun osuutta koko rehuannoksesta. Esimerkiksi karkearehun NDF-kuidun osuus $20 \%$ rehuannoksesta voisi olla kohtuullisen turvallinen suositus kasvavalle naudalle (Huhtanen Pekka, kirjallinen tiedonanto 22.3.2007). Tällä karkearehusta peräisin olevalla kuitumäärällä pitäisi saavuttaa hyvät kasvut ja pötsin toimia hyvin.

Kuvassa 1 on nähtävissä maitorotuisten sonnien NDF-kuidun saanti karkearehusta MTT:1lä toteutetussa ruokintakokeessa (Huuskonen ym. 2007) 30, 50 ja 70 prosentin väkirehutasoilla ruokittaessa. Sonnit ruokittiin kokeessa nurmisäilörehulla, ohralla ja rypsillä. Säilörehun keskimääräinen D-arvo koesarjan aikana oli 67. Kokeen tarkemmat yksityiskohdat selviävät Huuskosen ym. (2007) julkaisusta. Tässä koesarjassa maitorotuisten sonnien NDF-kuidun saanti karkearehusta oli kokeen aikana 70 \%:n väkirehutasolla keskimäärin $17 \%$ rehun syönnistä ja saanti vaihteli hyvin vähän kokeen aikana (Kuva 1). Sonneilla ei havaittu tässä kokeessa terveysongelmia korkeimmalla väkirehutasolla ja eläinten kasvut olivat hyvät. Sen sijaan $70 \%$ :n väkirehutasolla havaittiin voimakasta heikkenemistä kuidun sulatuksessa (Huuskonen ym. 2007), mikä kertoo siitä, että potentiaalisesti sulavan kuidun sulatus todennäköisesti heikkeni pötsin pH:n laskun ja sitä seuranneen kuidun sulatusnopeuden heikkenemisen seurauksena.

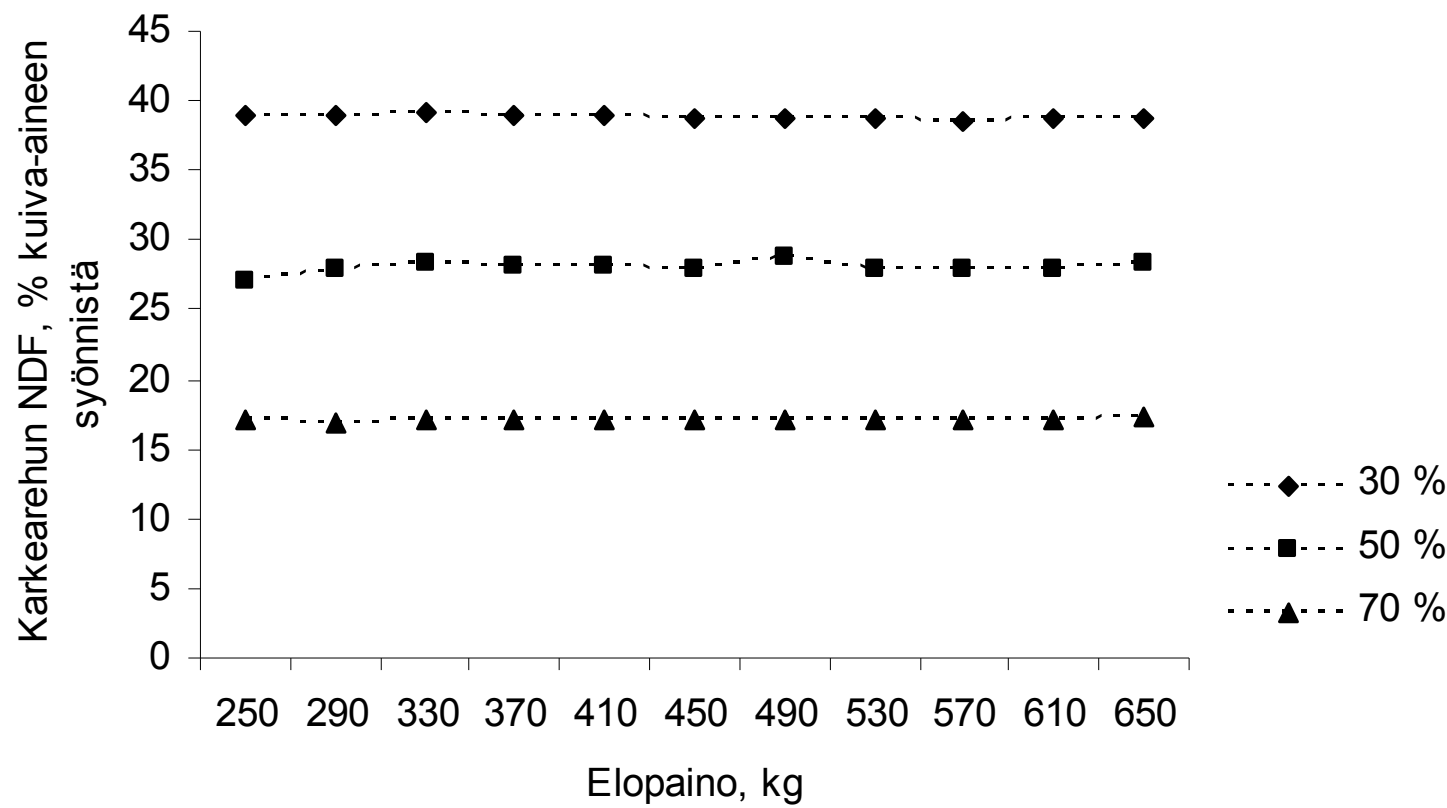

Kuva 1. Maitorotuisten sonnien NDF-kuidun saanti karkearehusta (nurmisäilörehu) 30, 50 ja 70 prosentin väkirehutasoilla ruokittaessa. Kuidun saanti on laskettu MTT:llä toteutetun ruokintakokeen (Huuskonen ym. 2007) tulosten perusteella.

\section{Nurmisäilörehun säilönnällinen laatu}

Säilörehun käymislaatu vaikuttaa voimakkaasti naudan vapaaehtoisesti syömän rehun määrään ja sitä kautta myös eläimen käytettäväksi tulevien ravintoaineiden määriin ja suhteisiin (Huhtanen ym. 2007). Esimerkiksi säilörehun korkea ammoniumtyppi- ja voihappopitoisuus alentavat vapaaehtoista rehun 
syöntiä, ja ovat merkkejä siitä, että säilörehu on virhekäynyttä ja/tai rehun käymisprosessi on ollut liiallista. Tällaisissa tapauksissa rehu on yleensä tehty ilman säilöntäainetta tai säilötty biologisilla säilöntäaineilla. Esimerkiksi märissä olosuhteissa biologisen säilönnän epäonnistumisriski on suuri (Jaakkola \& Saarisalo 2008). Märän rehun suurempi pilaantumisriski johtuu siitä, että biologisilla säilöntäaineilla säilöttävässä rehumassassa pitäisi olla sokeria noin $2,5 \%$ rehumassan tuorepainosta.

Näin ollen rehumassan kuiva-ainepitoisuus tulisi olla 30-35 \%, jotta sokerimäärä olisi riittävä (Jaakkola \& Saarisalo 2008).

Säilöntäainehapot, joista muurahaishappo on yleisin, laskevat suoraan rehun pH:ta (Jaakkola \& Saarisalo 2008). Tämän lisäksi säilyvyys perustuu osittain myös luontaiseen maitohappokäymiseen. Alhainen $\mathrm{pH}$ lopettaa mikrobitoiminnan lisäksi kasvientsyymien toiminnan ja soluhengityksen. Tällöin sokerin kulutus ja rehun lämpeneminen loppuvat. Säilöntähapoilla on pH-vaikutuksen lisäksi muitakin ominaisuuksia, jotka estävät haittamikrobien kasvua. Propioni-, bentsoe- ja sorbiinihappo estävät erityisesti homeiden ja hiivojen toimintaa.

Hapolla säilötty säilörehu sisältää yleensä enemmän sokereita ja vähemmän käymishappoja kuin pitkälle käynyt rehu (painorehu, entsyymi ja/tai bakteerivalmisteilla säilötty rehu) (Rinne 1995). Myös valkuaisen hajoaminen on hapolla säilötyssä säilörehussa vähäisempää kuin pitkälle käyneessä rehussa. Hapolla säilötty rehu tuottaa pötsikäymisessä vähemmän propionihappoa ja enemmän mikrobivalkuaista kuin pitkälle käynyt rehu (Jaakkola 1992). Kotimaisten säilörehututkimusten (Jaakkola ym. 1990, 2006) perusteella rehun säilöntä vaikuttaakin selvästi naudan pötsissä tapahtuvaan mikrobivalkuaisen tuotantoon. Kun tutkimuksissa on ruokittu nautoja joko rajoitetusti käyneellä, muurahaishapolla säilötyllä säilörehulla tai pitemmälle käyneellä, biologisesti säilötyllä rehulla tulokset ovat olleet selkeitä. Pötsin mikrobivalkuaisen tuotanto on tehostunut merkitsevästi happosäilöttyjä rehuja käytettäessä. Kasvavan lihanaudan ruokinnassa tämä tarkoittaa muun muassa sitä, että kun käytetään rajoitetusti käynyttä säilörehua, on rehuvalkuaisen tarve pienempi kuin pitkälle käynyttä säilörehua käytettäessä. Eräisiin biologisiin säilöntäaineisiin on lisätty entsyymejä, joiden tehtävänä on hajottaa rehun kuidusta sokeria maitohapon tuottamiseksi ja rehun riittävän happamuuden saavuttamiseksi. Teoriassa näin voi toki tapahtua, mutta on myös huomattava, että tämä saattaa johtaa liialliseen käymiseen. Rehun liiallinen käyminen puolestaan heikentää rehun valkuaisarvoa ja syöntipotentiaalia.

Valmiin säilörehun sokeripitoisuuden avulla voidaan arvioida säilöntäprosessia (Jaakkola \& Saarisalo 2008). Säilöntähappoja käytettäessä sokeria kuluu käymiseen vähemmän ja pitoisuus rehussa on tyypillisesti suurempi kuin biologisia valmisteita käytettäessä. Hyvin pieni sokeripitoisuus rehussa osoittaa, että sokerit ovat kuluneet käymisprosessissa. Tällöin sokeri on saattanut loppua kesken ja maitohappokäyminen ei ole ollut riittävää. Jos myös $\mathrm{pH}$ on korkea ja/tai virhekäymishappojen sekä ammoniakin pitoisuudet ovat suuria, on säilöntä selvästi epäonnistunut. Jos sen sijaan sokeripitoisuus on pieni ja kaikki muut kriteerit ovat kunnossa, ei pieni sokeripitoisuus sinällään osoita huonoa laatua. Mikäli rehun käymisprosessi ei ole saavuttanut stabiilia tilannetta, on pieni sokeripitoisuus aina riski rehun säilönnälliselle laadulle (Jaakkola \& Saarisalo 2008).

\section{Yhteenveto ja johtopäätökset}

Kasvukauden edetessä nurmikasvuston kuiva-ainesato kasvaa, mutta sadon ravitsemuksellinen arvo heikkenee, koska nurmikasvin solujen seinämät paksuuntuvat eli rehun kuitupitoisuus kasvaa. Ruokintakokeissa aikaisin korjattua säilörehua saaneet naudat ovat yleensä kasvaneet nopeammin kuin myöhemmin korjatulla säilörehulla ruokitut naudat. Nautojen ruokinnassa sulavan orgaanisen aineen määrä rehun kuiva-aineessa eli D-arvo on Suomessa tärkein karkearehun ravitsemuksellista laatua kuvaava tekijä. Kaikille lihanautatiloille sopivaa nurmisäilörehun D-arvotavoitetta on kuitenkin mahdoton antaa, koska se riippuu mm. käytettävissä olevasta peltopinta-alasta.

Säilörehun korkea raakavalkuaispitoisuus vaikuttaa negatiivisesti typen hyväksikäyttöön ja lisää kotieläintuotannon ympäristökuormitusta. Typen hyväksikäytön kannalta ihanteellisessa säilörehussa olisi raakavalkuaista 12-13\% ja rehun sulavuus olisi hyvä (D-arvo yli 67). NDF-kuidun osalta minimitasoa kasvavalle lihanaudalle ei voida vielä nykytietämyksellä antaa. Jos rehuannoksesta $20 \%$ on karkearehun NDF-kuitua, ollaan vielä todennäköisesti pötsin toiminnan kannalta turvallisella tasolla.

Säilörehun käymislaatu vaikuttaa voimakkaasti naudan vapaaehtoisesti syömän rehun määrään ja sitä kautta myös eläimen käytettäväksi tulevien ravintoaineiden määriin ja suhteisiin. Esimerkiksi säilörehun korkea ammoniumtyppi- ja voihappopitoisuus alentavat vapaaehtoista rehun syöntiä, ja ovat merkkejä siitä, että säilörehu on virhekäynyttä ja/tai rehun käymisprosessi on ollut liiallista. Re- 
hun säilöntä vaikuttaa selvästi myös naudan pötsissä tapahtuvaan mikrobivalkuaisen tuotantoon. Kun tutkimuksissa on ruokittu nautoja joko rajoitetusti käyneellä, muurahaishapolla säilötyllä säilörehulla tai pitemmälle käyneellä, biologisesti säilötyllä rehulla tulokset ovat olleet selkeitä. Pötsin mikrobivalkuaisen tuotanto on tehostunut merkitsevästi happosäilöttyjä rehuja käytettäessä. Kasvavan lihanaudan ruokinnassa tämä tarkoittaa muun muassa sitä, että kun käytetään rajoitetusti käynyttä säilörehua, on rehuvalkuaisen tarve pienempi kuin pitkälle käynyttä säilörehua käytettäessä.

\section{Kirjallisuus}

Aronen, I. \& Toivonen, V. 1995. Säilörehun korjuuasteen ja väkirehutäydennyksen vaikutukset tuotannon tehokkuuteen naudalla. Teoksessa: Säilörehun laadun ja väkirehutäydennyksen vaikutukset naudanlihatuotantoon. Maatalouden tutkimuskeskus. Tiedote 12/95: s. 33-45.

Aronen, I., Toivonen, V. \& Joki-Tokola, E. 1995. Rehunurmen typpilannoituksen ja korjuuajankohdan sekä väkirehutäydennyksen vaikutukset säilörehun hyväksikäyttöön naudalla. Teoksessa: Säilörehun laadun ja väkirehutäydennyksen vaikutukset naudanlihatuotantoon. Maatalouden tutkimuskeskus. Tiedote 12/95: s. 47-58.

Chamberlain, D.G. 1987. The silage fermentation in relation to the utilization of nutrients in the rumen. Proc. Biochem. 22:60-63.

Flipot, P., Wesley, M. \& Lalande, G. 1984. Chemical composition and animal performance of grass forage of varying maturity stored as hay or silage. Anim. Feed Sci. Technol. 11: 35-44.

Galyean, M.L. \& Eng, K.S. 1998. Application of research findings and summary of research needs: Bud Britton Memorial Symposium on Metabolic Disorders of Feedlot Cattle. J. Anim. Sci. 76: 323-327.

Huhtanen, P. 2003. Kuidun ja sen laadun merkitys lypsylehmien ruokinnassa. Maito ja me 15 (6/2003): 18-19.

Huhtanen, P., Rinne, M. \& Nousiainen, J. 2007. Evaluation of the factors affecting silage intake of dairy cows: a revision of the relative silage dry-matter intake index. Animal 1: 758-770.

Huuskonen, A. 2009. Concentrate feeding strategies for growing and finishing dairy bulls offered grass silagebased diets. MTT Science 1: $99 \mathrm{~s}$. Väitöskirja.

Huuskonen, A., Khalili, H. \& Joki-Tokola, E. 2007. Effects of three different concentrate proportions and rapeseed meal supplement to grass silage on animal performance of dairy-breed bulls with TMR feeding. Livest. Sci. 110: 154-165.

Huuskonen, A. \& Ojajärvi, P. 2006. Naudanlihantuotanto ja ympäristö. Teoksessa: Susanna Tauriainen (toim.). Naudanlihantuotanto. Jyväskylä: Gummerus Kirjapaino . s. 211-217.

Jaakkola, S., Huhtanen, P. \& Vanhatalo, A. 1990. Fermentation quality of grass silage treated with enzymes or formic acid and nutritive value in growing cattle fed with or without fish meal. Acta Agric. Scand. 40: 403414.

Jaakkola, S., Kaunisto, V. \& Huhtanen, P. 2006. Volatile fatty acid proportions and microbial protein synthesis in the rumen of cattle receiving grass silage ensiled with different rates of formic acid. Grass For. Sci. 61: $282-292$.

Jaakkola, S. \& Saarisalo, E. 2008. Sokerin rooli rehun säilönnässä. Maito ja Me 20 (3/2008): 16-17.

Joki-Tokola, E., Aronen, I. \& Vehkaoja, H. 1995. Rehunurmen typpilannoituksen ja säilörehun korjuuajankohdan sekä väkirehutäydennyksen vaikutukset säilörehun hyväksikäyttöön naudalla. Teoksessa: Säilörehun laadun ja väkirehutäydennyksen vaikutukset naudanlihantuotantoon. Maatalouden tutkimuskeskus. Tiedote 12/95: s. 59-70.

Kuoppala, K., Rinne, M., Nousiainen, J. \& Huhtanen, P. 2004. Säilörehun ensi- ja jälkikasvun korjuuajan sekä väkirehutäydennyksen vaikutus lypsylehmien maidontuotantoon. Teoksessa: Toim. Anneli Hopponen ja Marketta Rinne. Maataloustieteen Päivät 2004, 12.-13.1.2004 Viikki, Helsinki [:esitelmät ja posterit]. Suomen maataloustieteellisen seuran tiedote 19: $6 \mathrm{~s}$.

Lindberg, J.E. \& Lindgren, E. 1988. Influence of cutting time and N fertilization on the nutritive value of timothy. 1. Rumen degradability of cell walls, in vivo digestibility and estimated energy and protein values. Swed. J. Agric. Res. 18: 91-98.

Mader, T.L., Dahlquist, J.M. \& Schmidt, L.D. 1991a. Roughage sources in beef cattle finishing diets. J. Anim. Sci. 69: 462-471.

Mader, T.L., Dahlquist, J.M., Britton, R.A. \& Krause, V.E. 1991b. Type and mixtures of high-moisture corn in beef cattle finishing diets. J. Anim. Sci. 69: 3480-3486.

Manninen, M., Nykänen, A., Jauhiainen, L. \& Volanto, P. 2006. Nurmisäilörehun D-arvon ja väkirehun valkuaispitoisuuden vaikutus hereford-sonnien loppukasvatuksessa : a) tuotantotulokset sekä ruhon ja lihan laatu. Teoksessa: Toim. Anneli Hopponen. Maataloustieteen Päivät 2006, 11.-12.1.2006 Viikki, Helsinki (:esitelmät ja posterit). Suomen maataloustieteellisen seuran tiedote 21: $7 \mathrm{~s}$.

Martinsson K. 1990. The effect of forage digestibility and concentrate supplementation on performance of finishing bulls. Swed. J. Agric. Res. 20: 161-167. 
Muir, P.D., Deaker, J.M. \& Bown, M.D. 1998. Effects of forage- and grain-based feeding systems on beef quality: A review. New Zealand J. Agric. Res. 41: 623-635.

Nagaraja, T.G. \& Chengappa, M.M. 1998. Liver abscesses in feedlot cattle: a review. J. Anim. Sci. 76 : $287-$ 298.

Nordang, L.Ø. \& Hole, J.R. 1987. Feeding value of grass silage harvested 14 and 24 days after heading to growing bulls. Norsk landbruksforsking 1: 181-188.

Owens, F.N., Secrist, D.S., Hill, W.J. \& Gill, D.R. 1998. Acidosis in cattle: a review. J. Anim. Sci. 76: $275-$ 286.

Prins, R.A. 1977. Biochemical activities of gut micro-organisms. Teoksessa: Clarke, R.T.J. \& Bauchop, T. (Toim.). Microbial Ecology of the gut. Academic Press, London. s. 73-183.

Ramsey, P.B., Mathison, G.W. \& Goonewardene, L.A. 2002. Effect of rates and extent of ruminal barley grain dry matter and starch disappearance on bloat, liver abscesses, and performance of feedlot steers. Anim. Feed Sci. Technol. 97: 145-157.

Rinne, M. 1995. Säilörehun laadun ja väkirehutäydennyksen vaikutukset naudanlihatuotantoon. Yhteenveto. Teoksessa: Säilörehun laadun ja väkirehutäydennyksen vaikutukset naudanlihatuotantoon. Maatalouden tutkimuskeskus. Tiedote 12/95: s. 7-12.

Rinne, M. 2000. Influence of the timing of the harvest of primary grass growth on herbage quality and subsequent digestion and performance in the ruminant animal. Helsingin yliopiston kotieläintieteen laitoksen julkaisuja 54: 42 s. +5 liitettä. Helsinki: Helsingin yliopisto, 2000. (Väitöskirja).

Rinne, M., Jaakkola, S., Vanhatalo, A., Huhtanen, P. \& Toivonen, V. 1995. Rehunurmen typpilannoituksen ja kasvuasteen vaikutukset säilörehun sulatukseen naudalla. Teoksessa: Säilörehun laadun ja väkirehutäydennyksen vaikutukset naudanlihatuotantoon. Maatalouden tutkimuskeskus. Tiedote 12/95: s. 13-32.

Steen, R.W.J. 1984. A comparison of two-cut and three-cut systems of silage making for beef cattle using two cultivars of perennial ryegrass. Anim. Prod. 38: 171-179.

Steen, R.W.J. 1992. The performance of beef cattle given silage made from perennial ryegrass of different maturity groups, cut on different dates. Grass For. Sci. 47: 239-248.

Steen, R.W.J., Kilpatrick, D.J. \& Porter, M.G. 2002. Effects of the proportions of high or medium digestibility grass silage and concentrates in the diet of beef cattle on liveweight gain, carcass composition and fatty acid composition of muscle. Grass For. Sci. 57: 279-291.

Steen, R.W.J. \& McIlmoyle, W.A. 1982. The effect of frequency of harvesting grass for silage and level of concentrate supplementation on the intake and performance of beef cattle. Anim. Prod. 35: 245-252.

Steen, R.W.J. \& McIlmoyle, W.A. 1985. The effect of frequency of harvesting grass for silage on the intake and performance of beef cattle. Grass For. Sci. 40: 341-347.

Tamminga, S. 1992. Nutrition management of dairy cows as a contribution to pollution control. J. Dairy Sci. 75 : 345-357.

Thorvaldson, G. \& Andersson, S. 1986. Variations in timothy dry matter yield and nutritional value as affected by harvest date, nitrogen fertilization, year and location in Northern Sweden. Acta Agric. Scand. 36: 367-385.

Tuori, M. 1992. Rapeseed meal as a supplementary protein for dairy cows on grass silage-based diet, with emphasis on the Nordic AAT-PBV feed protein evaluation system. Agric. Sci. Finl. 1: 367-439.

Van Vuuren, A.M., Krol-Kramer, F., Van der Lee, R.A. \& Corbijn, H. 1992. Protein digestion and intestinal amino acids in dairy cows fed fresh Lolium perenne with different nitrogen contents. J. Dairy Sci. 75: 22152225 .

Van Soest, P.J., Robertson, J.B. \& Lewis, B.A. 1991. Methods for dietary fibre, neutral detergent fibre and nonstarch polysaccharides in relation to animal nutrition. J. Dairy Sci. 74: 3583-3597.

Varvikko, T., Jaakkola, S., Rinne, M. \& Huhtanen, P. 1995. Rypsirouheen ja lämpökosteuskäsitellyn rypsipuristeen valkuaisarvo maidontuotannossa säilörehuruokinnalla. Kotieläintieteen päivät 1995. Maaseutukeskusten liiton julkaisuja numero 888. s. 35-40. 